\title{
Identifikasi Isolat Antikanker Spons Hyrtios Erecta
}

\author{
I MADE DIRA SWANTARA ${ }^{1}$, WIWIK SUSANAH RITA ${ }^{1}$, DAN ANISA HERNINDYA² \\ ${ }^{1}$ Staf Pengajar padaProgram Studi Kimia Terapan, Program Pascasarjana, Universitas Udayana \\ ${ }^{2}$ Mahasiawa Program Magister Kimia Terapan, Program Pascasarjana, Universitas Udayana
}

Diterima: 17 Oktober 2016; Direview: 19 Oktober 2016; Disetujui: 28 Oktober 2016

\begin{abstract}
Isolation, anticancer activity test, and identification of the toxic isolate from ethanol extract of the sponge Hyrtios erecta taken from Pari Island beach (Jakarta) has conducted. Extraction of the sponges was carried out by $70 \%$ ethanol at room temperature. Partition and purification of the compounds were done by column chromatography with the stationary phase of silica gel and the mobile phase of n-hexane-chloroform (2:8). Toxicity screening test was done based on Bhrine Shrimp Lethality Test (BSLT). In vitro anticancer activity test of the isolate was carried out using HeLa cell line. Identification of the compounds was performed by Gas chromatography-mass spectroscopy (GC-MS). Based on the results, it was found that the toxic isolate of $H$. erecta sponges has anticancer activity with $I_{50}$ of 30,497 ppm. Four compounds was detected from the anticancer isolate i.e: 4-nonylphenol; dibutyl phthalate; hexanedioic acid bis(2ethylhexyl) ester; and cholesterol.
\end{abstract}

Keyword: anticancer activity; Hela cell line, Hyrtios erecta

\section{ABSTRAK}

Telah dilakukan isolasi, uji aktivitas antikanker, dan identifikasi isolat toksik yang berasal dari ekstrak etanol spons Hyrtios erecta yang diambil dari perairan Pulau Pari (Jakarta). Ekstraksi dilakukan dengan cara maserasi menggunakan etanol 70\% pada temperatur kamar. Pemisahan dan pemurnian komponen menggunakan kromatografi kolom dengan fase diam silikagel dan fase gerak $n$-heksana-kloroform (2:8). Skrining toksisitas dilakukan dengan metode Bhrine Shrimp Lethality Test (BSLT). Uji antikanker secara in vitro isolat toksik tersebut menggunakan sel HeLa. Senyawanya diidentifikasi menggunakan Gas chromatography-mass spectroscopy (GC-MS). Berdasarkan hasil penelitian ini diperoleh bahwa isolat toksik spons $H$. erecta bersifat antikanker dengan IC $_{50}$ sebesar 30,497 ppm. Pada isolat antikanker tersebut terdeteksi empat senyawa, yaitu 4-nonylphenol; dibutil phtalat; ester heksadioat bis(2-etilheksil); dan kolesterol.

Kata Kunci: antikanker; sel HeLa; Hyrtios erecta

\section{KORESPONDENSI:}

I Made Dira Swantara

Staf Pengajar Program Studi Kimia Terapan, Program Pascasarjana, Universitas Udayana Email: m_dira_swantara @yahoo.co.id

\section{PENDAHULUAN}

$\mathcal{C}$ at ini, kanker adalah salah satu penyebab utama kematian di negara berkembang. $\checkmark$ Di Amerika Serikat dan beberapa negara berkembang lain, kanker saat ini bertanggung jawab terhadap sekitar 25\% dari seluruh kematian. Dalam setahun, sekitar 0,5\% dari populasi kematian terdiagnosis kanker. ' WHO juga menyatakan bahwa sepertiga sampai setengah dari jenis kanker bisa dicegah. Sepertiga lagi dapat disembuhkan 
bila ditemukan dan diobati sejak tahap awal/stadium dini, namun sisanya hanya dapat diringankan penderitaannya.

Meskipun usaha pengobatan kanker secara intensif telah dilakukan, hingga kini belum ditemukan obat yang dapat mengatasi penyakit tersebut secara memuaskan. Hal ini disebabkan rendahnya selektivitas obat-obat yang digunakan. ${ }^{2}$ Berbagai macam senyawa telah dikembangkan untuk melawan kanker yang meliputi senyawa-senyawa pengalkilasi, antimetabolit, obat-obat radiomimetik, hormon, dan senyawa antagonis. 3,4,5,6 Akan tetapi, tak satu pun jenis senyawa-senyawa ini menghasilkan efek yang memuaskan dan tanpa efek samping yang merugikan. ${ }^{7,8}$ Kemoterapi merupakan salah satu pengobatan utama kanker, tetapi toksisitas dan efek sampingnya sangat besar. Oleh karena itu, diperlukan alternatif obat tradisional dengan menggunakan bahan lokal yang lebih murah, mudah didapat, juga tanpa meninggalkan efek samping bagi pasien. Itulah yang menyebabkan pada saat ini mulai banyak dilakukan penelitian tentang bahan obat antikanker yang berasal dari alam. Pencarian bahan aktif antikanker dari alam bukan hanya yang berasal dari organisme darat, tetapi sudah merambah ke organisme lautan.

Keanekaragaman hayati perairan laut Indonesia memberi peluang untuk memanfaatkan biota laut untuk pencarian senyawa bioaktif yang baru, salah satunya adalah spons. Spons merupakan salah satu komponen biota penyusun ekosistem terumbu karang yang mempunyai potensi bioaktif. Senyawa bioaktif yang dihasilkan spons laut merupakan sumber senyawa-senyawa baru yang memiliki aktivitas farmakologis sehingga dapat digunakan sebagai obat karena memiliki sifat toksik untuk membunuh sel kanker. ${ }^{9}$ Berbagai penelitian telah dilakukan untuk mengidentifikasi aktivitas biologis yang dimiliki oleh spons dari jenis $H$. erecta. Pettit menyebutkan bahwa $H$. erecta mengandung beberapa senyawa aktif, seperti spongistatin sebagai senyawa antikanker, senyawa 15-oxopupeheonol sebagai penghambat sel kanker dan malaria, sesterpen 1 yang menghambat sel leukemia, dan dipupehedion sebagai penghambat sel kanker. ${ }^{10}$

Salah satu metode yang digunakan untuk skrining awal terhadap senyawa aktif antikanker adalah uji sitotoksisitas terhadap larva Artemia salina Leach atau Brine Shrimp Lethality Test (BSLT). ${ }^{11,12}$ Toksisitas yang tinggi dari senyawa uji sangat berkorelasi dengan aktivitas senyawa sebagai antikanker. ${ }^{13}$ Suatu bahan yang mempunyai toksisitas dengan letal concentration $50\left(\mathrm{LC}_{50}\right)$ lebih rendah dari 1000 ppm berpotensi sebagai agen antikanker dan dapat dilakukan uji lanjutan antikanker terhadap sel HeLa. Sel HeLa merupakan sel manusia yang umum digunakan untuk kepentingan kultur sel. ${ }^{14}$

Penelitian ini bertujuan untuk mengidentifikasi senyawa yang terkandung di dalam isolat yang bersifat antikanker yang berasal dari ekstrak etanol spons $H$. erecta yang sudah terbukti memiliki aktivitas antikanker terhadap sel HeLa. ${ }^{15}$

\section{MATERI DAN METODE}

Spons $H$. erecta yang diambil dari perairan Pulau Pari, Kepulauan Seribu, Jakarta, pada 1 Agustus 2016 (memperbanyak sampel). Sampel tersebut dibersihkan dari pengotornya dengan air kran sampai bersih, kemudian di kering anginkan selama beberapa hari. Setelah kering selanjutnya dihaluskan dengan blander sampai tingkat kehalusan 100 mesh. Selanjutnya, sebanyak 500 gram serbuk sampel dimaserasi dengan etanol 70\% sampai terendam dan dibiarkan selama 24 jam, kemudian disaring. Filtratnya dikumpulkan dan ampasnya ditambahi lagi pelarut yang sama sampai terendam. Pekerjaan ini diulangi 3-4 kali sampai diperkirakan semua senyawa terekstraksi. Filtrat yang terkumpul diuapkan dengan penguap putar vakum sampai semua pelarutnya menguap sehingga diperoleh ekstrak kasar (Crude extract).

Ekstrak kasar di atas selanjutnya dilarutkan ke dalam campuran etanol-air (3:7) sebanyak $250 \mathrm{~mL}$ sampai semua larut, kemudian diuapkan etanolnya sampai semua etanol menguap sehingga tersisa ekstrak di dalam pelarut air. Terhadap ekstrak air ini, dipartisi dengan n-heksana (3 x 100 mL). Lapisan n-heksana dipisahkan dan lapisan air dipartisi kembali dengan kloroform (3 x $100 \mathrm{~mL}$ ), lalu dipisahkan sehingga diperoleh ekstrak n-heksana $(E H)$, ekstrak kloroform (EK), dan ekstrak air (EW). Ketiga ekstrak tersebut diuapkan sampai pelarutnya habis. Terhadap ketiga ekstrak di atas dilakukan uji toksisitas terhadap larva A. salina L. Ekstrak yang paling toksik, selanjutnya dipisahkan.

Sebanyak 2 gram ekstrak paling toksik di atas dipisahkan menggunakan kromatografi kolom siliga gel (100 gram) dengan eluen terbaik hasil pencarian dengan kromatografi lapis tipis (KLT). Eluat ditampung setiap $5 \mathrm{~mL}$ pada botol tertentu sampai diperkirakan semua komponen keluar dari kolom. Semua eluat dilihat pola nodanya pada KLT. Eluat dengan pola noda sama digabungkan sehingga 
diperoleh beberapa fraksi. Semua fraksi yang diperoleh diuji toksisitasnya kembali terhadap larva A. salina L. Fraksi yang paling toksik selanjutnya diuji aktivitas antikanker terhadap sel HeLa dan diidentifikasi senyawa yang dikandungnya.

Uji toksisitas menggunakan bioindikator larva A. salina L. mengikuti metode Meyer. ${ }^{13}$ Media untuk menetaskan larva $A$. salina $L$ dibuat dengan menyaring air laut secukupnya. Air laut dimasukkan ke dalam akuarium yang dibagi menjadi dua bagian, yaitu satu bagian dibuat gelap yang ditutup dengan kertas hitam dan bagian yang lain dibiarkan terbuka. Telur A. salina L. diletakkan secukupnya pada bagian yang gelap dan dibiarkan selama 2 x 24 jam sehingga telur menetas menjadi larva yang siap digunakan untuk pengujian.

Seberat 20 mg bahan yang akan diuji dilarutkan dalam $2 \mathrm{~mL}$ pelarut $n$-heksana. Dari larutan ini diambil sebanyak 500, 50, dan $5 \mu \mathrm{L}$, kemudian masing-masing dimasukkan ke dalam tabung reaksi dan pelarutnya diuapkan ke dalam masing-masing tabung reaksi ditambahi $1 \mathrm{~mL}$ air laut, $50 \mu \mathrm{L}$ dimetilsulfoksida, dan 10 ekor larva. Kemudian ditambahi air laut sampai volumenya $5 \mathrm{~mL}$ sehingga diperoleh konsentrasi ekstrak pada masing-masing tabung: 1000; 100; dan 10 ppm. Dibuat juga konsentrasi ekstrak 0 ppm (tanpa penambahan ekstrak) sebagai kontrol. Masing-masing tabung reaksi ditutup dengan aluminium foil dan dilubangi sedikit lalu dibiarkan pada suhu kamar. Setelah 24 jam dilakukan pengamatan terhadap kematian larva. Jumlah larva yang mati dicatat, kemudian dilakukan penghitungan $\mathrm{LC}_{50}$.

Uji antikanker menggunakan sel HeLa. Sel kanker serviks (HeLa) dikultur pada media RPMI 1640, dihitung jumlah awal sel di bawah mikroskop. Kemudian sel dipanen dengan penambahan tripsin. Selanjutnya sel disentrifugasi hingga terbentuk dua lapisan (endapan dan supernatan). Supernatan dibuang dan endapannya dibentuk pelet serta ditambahkan media komplit $1 \mathrm{~mL}$, kemudian dihitung jumlah selnya menggunakan hemositometer. Setelah sel mencukupi, sel ditanam pada microwell plate 96 sumuran. Tiap sumuran berisi 2x104 sel dalam $100 \mu \mathrm{L}$. Inkubasi sel selama 1-2 jam sehingga sel melekat. Setelah itu ditambahkan ekstrak bahan uji dengan berbagai konsentrasi (1000; 500; 250; 125; 62,$5 ; 31,25 ; 15,62 ; 7,81 ; 3,91 ; 1,95 ; 0,97 ; 0,48 ; 0,24$; 0,12 ; dan $0,06 \mu \mathrm{g} / \mathrm{mL}$ ) pada setiap well sebanyak 100 $\mu \mathrm{L}$. Jadi, total setiap well berisi $200 \mu \mathrm{L}$. Inkubasi dalam inkubator selama 24 jam pada suhu $37^{\circ} \mathrm{C}$. Setelah 24 jam dilihat di bawah mikroskop, ditambahkan MTT (3-(4,5-dimetiltiazol-2-il)-2,5difeniltetrazolium bromida) $(5 \mu \mathrm{g} / \mathrm{lmL})$ pada tiap-tiap well, kemudian diinkubasi selama 4 jam. Selanjutnya, larutan stop SDS (sodium dodesil sulfat) 10\% dalam $0,01 \mathrm{~N} \mathrm{HCl}$ ditambahkan pada tiap-tiap well dan diinkubasi kembali satu malam. Absorbansinya dibaca menggunakan ELISA reader pada panjang gelombang $550 \mathrm{~nm}$.

\section{HASIL DAN PEMBAHASAN}

Ekstraksi 500 gram serbuk sampel spons $H$. erecta menggunakan etanol 70\% menghasilkan ekstrak kental etanol berwarna coklat seberat 21,70 gram. Menurut Sadek, etanol dengan indeks polaritas 5,2 dan mempunyai kelarutan $100 \%$ di dalam air akan melarutkan senyawa-senyawa yang bersifat polar. ${ }^{16}$ Selanjutnya, ekstrak etanol ini dipartisi ke dalam 3 pelarut yang mempunyai polaritas yang berbeda.

Semua ekstrak kental etanol ini dilarutkan dengan campuran etanol-air (3:7) sebanyak $250 \mathrm{~mL}$ sampai semua larut, kemudian etanolnya diuapkan sampai tersisa ekstrak dalam air. Ekstrtak air ini dipartisi berturut-turut dengan $n$-heksana dan kloroform yang selanjutnya diuapkan pelarutnya, menghasilkan ekstrak n-heksana 6,29 gram; ekstrak kloroform 3,28 gram; dan ekstrak air 8,13 gram.

Terhadap ketiga ekstrak hasil partisi di atas dilakukan uji toksisitas terhadap larva A. salina dengan hasil seperti pada Tabel 1.

Tabel 1: Hasil uji toksisitas ekstrak hasil partisi

\begin{tabular}{ll}
\hline Jenis ektrak & $\mathbf{L C}_{\mathbf{5 0}}$ (ppm) \\
\hline n-heksana & 316,22 \\
Kloroform & 501,18 \\
Air & 446,68 \\
\hline
\end{tabular}

Berdasarkan data Tabel 1 terlihat bahwa ekstrak $n$-heksana bersifat paling toksik dibandingkan dua ekstrak lain dengan nilai $\mathrm{LC}_{50}$ sebesar 316,22 ppm. Selanjutnya, ekstrak $n$-heksana ini dipisahkan dan dimurnikan.

Pemisahan komponen-komponen dalam ekstrak n-heksana di atas menggunakan metode kromatografi kolom silika gel 60 (70-230 mesh ASTM) dengan fase gerak campuran $n$-heksana - kloroform (2:8). Eluat ditampung setiap $5 \mathrm{~mL}$. Pada proses ini dihasilkan 168 botol eluat. Semua (168 botol eluat) ini dilihat pola nodanya menggunakan kromatografi lapis tipis. Berdasarkan pola noda, diperoleh 3 fraksi $\left(\mathrm{F}_{\mathrm{A}}, \mathrm{F}_{\mathrm{B}}\right.$, dan $\left.\mathrm{F}_{\mathrm{C}}\right)$ seperti terlihat pada tabel 2. 
Tabel 2: Hasil kromatografi kolom fraksi n-heksana

\begin{tabular}{ll}
\hline Fraksi & Eluat botol ke- \\
\hline$F_{A}$ & $1-55$ \\
$F_{B}$ & $56-123$ \\
$F_{C}$ & $124-186$ \\
\hline
\end{tabular}

Selanjutnya, ketiga fraksi tersebut diuji toksisitasnya sehingga menghasilkan data toksisitas seperti terlihat pada Tabel 3.

Tabel 3: Hasil uji toksisitas fraksi

\begin{tabular}{ll}
\hline Sampel & $\mathrm{LC}_{50}(\mathrm{ppm})$ \\
\hline $\mathrm{F}_{\mathrm{A}}$ & 794,32 \\
$\mathrm{~F}_{\mathrm{B}}$ & 50,11 \\
$\mathrm{~F}_{\mathrm{C}}$ & 630,95 \\
\hline
\end{tabular}

Hasil uji toksisitas di atas menjukkan bahwa fraksi $\mathrm{B}\left(\mathrm{F}_{\mathrm{B}}\right)$ paling toksik dibandingkan dengan $\mathrm{F}_{\mathrm{A}}$ dan $\mathrm{F}_{\mathrm{C}}$ dengan $\mathrm{LC}_{50}$ sebesar 50,11 ppm. Kalau kita bandingkan dengan toksisitas ekstrak n-heksana sebelumnya maka toksisitas $\mathrm{F}_{\mathrm{B}}$ lebih tinggi. Hal ini mengindikasikan bahwa senyawa-senyawa yang besifat tosik lebih terkonsentrasi pada $F_{B}$ dan senyawa-senyawa tersebut bersifat antagonis (semakin murni semakin toksik). Selanjutnya, terhadap fraksi $\mathrm{B}\left(\mathrm{F}_{\mathrm{B}}\right)$ ini dilakukan uji kemurnian.

Uji kemurnian isolat $F_{B}$ dilakukan dengan metode KLT menggunakan beberapa jenis fase gerak/eluen, dengan hasil uji seperti terlihat pada Tabel 4 .

Tabel 4: Hasil uji kemurnian isolate FB

\begin{tabular}{lllcl}
\hline Fase gerak/eluen & \multicolumn{3}{l}{ Warna noda pada UV } & Jumlah \\
& $254 \mathrm{~nm}$ & $366 \mathrm{~nm}$ & Noda & Rf \\
\hline Kloroform-etil asetat (2:3) & Coklat & Ungu & 1 & 0,92 \\
Kloroform-etanol (6:4) & Coklat & Ungu & 1 & 0,93 \\
n-heksana-kloroform (1:1) & Coklat & Ungu & 1 & 0,20 \\
n-heksana-kloroform (1:4) & Coklat & Ungu & 1 & 0,89 \\
\hline
\end{tabular}

Data Tabel 4 menunjukkan bahwa semua jenis eluen yang dicoba menghasilkan noda tunggal yang mengindikasikan isolat $\mathrm{F}_{\mathrm{B}}$ sudah murni secara KLT. Dengan demikian, terhadap isolat ini sudah bisa dilakukan uji aktivitas antikanker serta identifikasi senyawanya.
Aktivitas antikanker terhadap sel HeLa ditentukan dengan metode MTT. Prinsip dari uji MTT adalah terjadinya mekanisme perubahan warna kuning dari garam tetrazolium (3-(4,5-dimetiltiazol-2-il)-2,5difeniltetrazoliumbromida) yang tereduksi menjadi kristal formazan berwarna ungu dalam mitokondria sel hidup. MTT diabsorpsi ke dalam sel hidup dan dipecah melalui reaksi reduksi oleh enzim reduktase dalam rantai respirasi mitokondria menjadi formazan yang terlarut dalam SDS $10 \%$ berwarna ungu. ${ }^{17}$

Nilai absorban dari formazan yang terbentuk diukur dengan microplate reader pada panjang gelombang $595 \mathrm{~nm}$ dengan perlakuan triplo. Semakin kuat intensitas warna ungu yang terbentuk, absorbansi akan semakin tinggi. Hal ini menunjukkan bahwa semakin banyak MTT yang diabsorpsi ke dalam sel hidup dan dipecah melalui reaksi reduksi oleh enzim reduktase dalam rantai respirasi mitokondria sehingga formazan yang terbentuk juga semakin banyak.

Data yang diperoleh dari uji sitotoksisitas dengan MTT berupa nilai absorban atau optical density (OD), kemudian nilai rata-rata OD tersebut dikonversi menjadi \% inhibisi.

Hasil pengamatan absorbansi dan perhitungan $\%$ inhibisi sel HeLa setelah diberi isolat toksik $\left(\mathrm{F}_{\mathrm{B}}\right)$ ekstrak spons $H$. erecta disajikan pada Tabel 5 .

Tabel 5: Data absorbansi isolat toksik $\left(\mathrm{F}_{\mathrm{B}}\right)$

\begin{tabular}{llllll}
\hline $\begin{array}{l}\text { Sampel } \\
\text { (ppm) }\end{array}$ & OD1 & OD2 & OD3 & Rerata & $\begin{array}{l}\text { Inhibisi } \\
\text { (\%) }\end{array}$ \\
\hline 100 & 0,045 & 0,052 & 0,049 & 0,048 & 75,75 \\
50 & 0,062 & 0,056 & 0,03 & 0,049 & 75,25 \\
25 & 0,071 & 0,056 & 0,04 & 0,056 & 71,71 \\
12,5 & 0,075 & 0,063 & 0,07 & 0,069 & 65,15 \\
6,25 & 0,098 & 0,083 & 0,09 & 0,090 & 54,54 \\
3,125 & 0,102 & 0,100 & 0,100 & 0,100 & 49,49 \\
1,56 & 0,125 & 0,115 & 0,117 & 0,119 & 39,89 \\
0,78 & 0,166 & 0,158 & 0,167 & 0,163 & 17,67 \\
0,39 & 0,182 & 0,178 & 0,175 & 0,178 & 10,10 \\
0,195 & 0,185 & 0,187 & 0,185 & 0,186 & 6,06 \\
Cell control & 0,195 & 0,197 & 0,202 & 0,198 & 0,00 \\
\hline
\end{tabular}


Berdasarkan data pada Tabel 5, dapat dibuat hubungan antara konsentrasi sampel terhadap \% inhibisi untuk menghitung IC50. Adapun data hubungan konsentrasi sampel terhadap \% inhibisi terlihat pada Tabel 6.

Tabel 6: Data hubungan antara konsentrasi dengan inhibisi

\begin{tabular}{ll}
\hline Konsentrasi , x (ppm) & Inhibisi, $\mathbf{y}$ (\%) \\
\hline 100 & 75,75 \\
50 & 75,25 \\
25 & 71,71 \\
12,5 & 65,15 \\
6,25 & 54,54 \\
3,125 & 49,49 \\
1,56 & 39,89 \\
0,78 & 17,67 \\
0,39 & 10,10 \\
0,195 & 6,06 \\
0 & 0,00 \\
\hline
\end{tabular}

Berdasarkan data pada Tabel 6, dapat dibuat persamaan garis regrisi model: $\mathrm{y}=\mathrm{ax}+\mathrm{b}$, sehingga diperoleh persamaan garis regresi: $\mathrm{y}=0,624 \mathrm{x}+30,97$ $\left(\mathrm{R}^{2}=0,443\right)$. Adapun grafik hubungan antara konsentrasi sampel terhadap \% inhibisi untuk penentuan nilai IC $_{50}$ digambarkan pada Gambar 1.

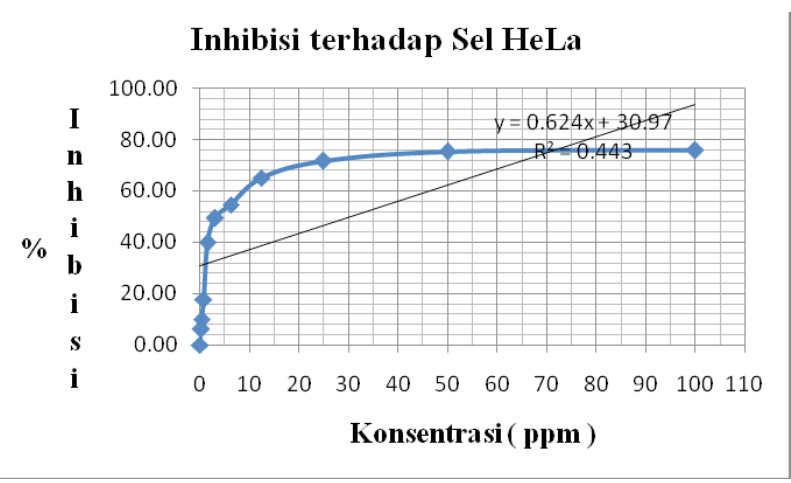

Gambar 1: Grafik hubungan konsentrasi terhadap \% inhibisi
Untuk menghitung $I_{50}$ sampel seperti pada Gambar 1 dapat dilakukan melalui persamaan regresi: $50=0,624 x+30,97 ; 0,624 x=50-30,97 ; x=30,497$. Jadi, IC $_{50}$ isolat toksik hasil isolasi ekstrak etanol spons $H$. erecta sebesar 30,497 ppm. Aktivitas antikanker sebesar 30,497 ppm dikategorikan ke dalam aktivitas sedang. ${ }^{18}$

Bila dibandingkan dengan $\mathrm{IC}_{50}$, ekstrak etanol spon $H$. erecta sebelum diisolasi sebesar 26,35 ppm menunjukkan terjadi penurunan aktivitas antikanker terhadap sel HeLa setelah dimurnikan. ${ }^{15}$ Hal ini membuktikan fenomena bahwa senyawa-senyawa yang mempunyai aktivitas biologis yang berasal dari bahan hayati umumnya bersifat sinergis.

Isolat yang aktif antikanker di atas $\left(F_{B}\right)$ diidentifikasi senyawa yang terkadung di dalamnya menggunakan GC-MS. Adapun kromatogram gas hasil analisis dengan GC terlihat seperti Gambar 2.

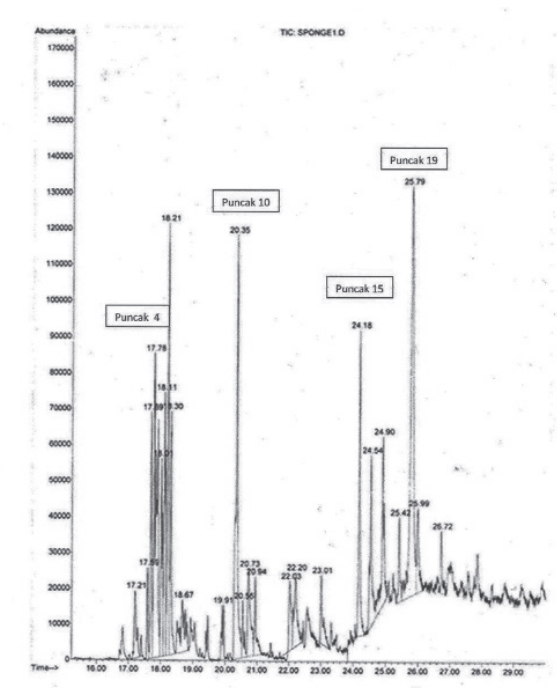

Gambar 2: Kromatogram gas $F_{B}$

Berdasarkan kromatogram gas di atas terlihat adanya 20 puncak yang mengindikasikan adanya 20 senyawa yang terkandung di dalam isolat tersebut. Dari 20 puncak yang dihasilkan, hanya empat puncak (puncak 4; 10; 15; dan 19) yang dapat dianalisis berdasarkan database MS. Sedangkan 16 puncak lain belum dapat dianalisis karena belum sesuai dengan database library MS sehingga diperlukan beberapa spektra tambahan seperti $\mathrm{H}-\mathrm{NMR}$ dan C-NMR. Analisis spektra massa keempat puncak di atas berdasarkan kecocokan dengan database NIST02.L diperoleh hasil seperti pada Tabel 7. 
Tabel 7: Senyawa yang teranalisis pada isolate aktikanker $\left(\mathrm{F}_{\mathrm{B}}\right)$

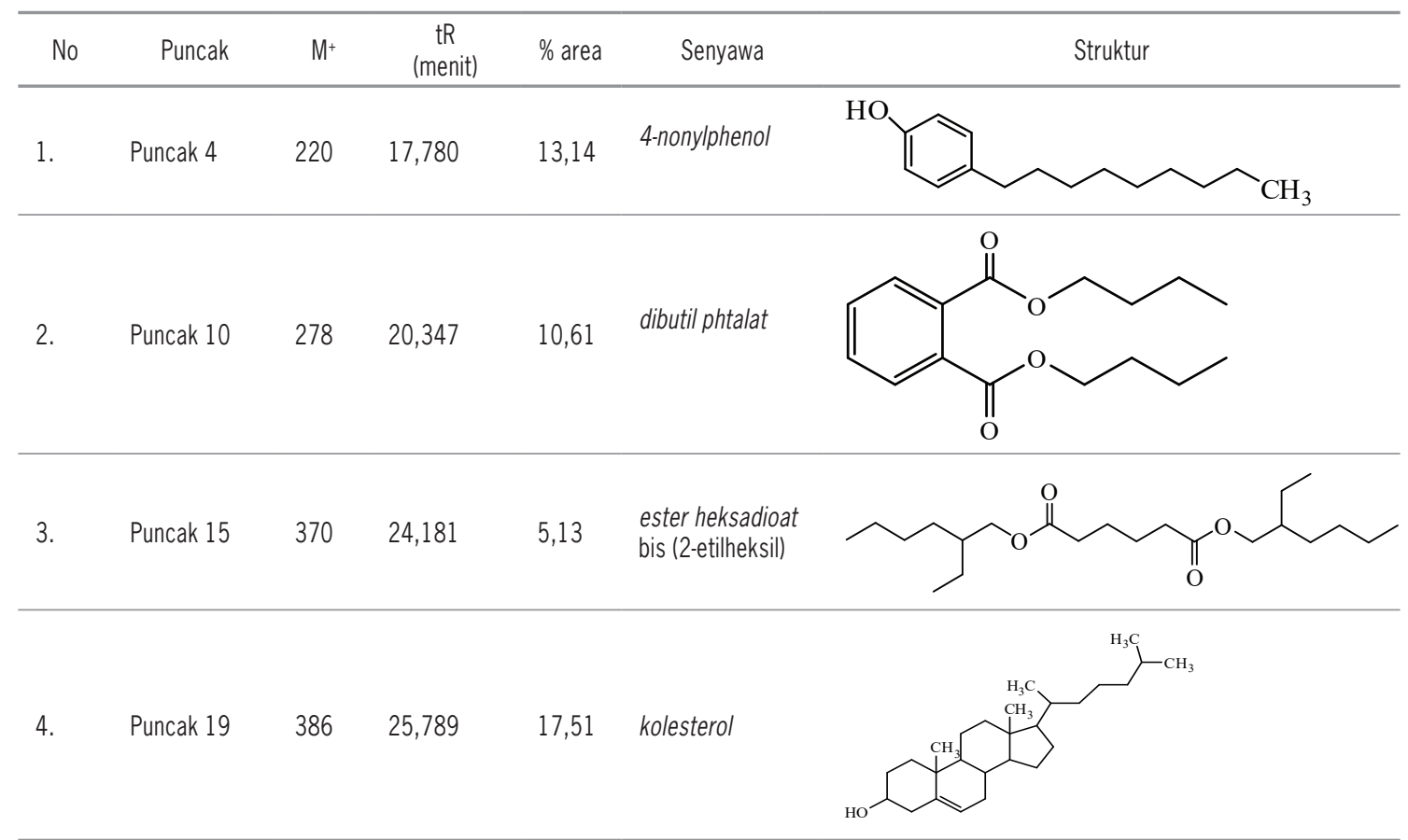

Di antara keempat senyawa yang berhasil diidentifikasi, terdapat senyawa yang diduga berperan penting terhadap aktivitas antikanker pada isolat yang bersifat antikanker pada spons $H$. Erecta, yaitu dibutil phtalat dan ester bis(2-etilheksil). Senyawa ester heksadioat bis(2-etilheksil) merupakan senyawa ester turunan asam karboksilat C16-C18. Beberapa penelitian serupa yang mendukung aktivitas senyawa tersebut dilaporkan antara lain oleh Ohashi, et al., yang melaporkan bahwa senyawa aktif yang diisolasi dari benalu teh, yaitu asam oktadeka-8,10,12-trinoat teruji secara in vitro dan in vivo bekerja menghambat invasi sel kanker sehingga sel tidak mengalami metastasis. ${ }^{19}$ Winarno dalam penelitiannya mengenai aktivitas antipoliferasi asam oktadeka-8,10,12-triunoat terhadap galur sel kanker manusia melaporkan bahwa senyawa tersebut memiliki aktivitas antiproliferasi terhadap empat jenis galur sel kanker manusia, yaitu sel HeLa, leukemia THPI, karsinoma paru-paru A549, dan limfoma HUT78 dengan nilai LC50 berturut-turut 0,66; 0,86; 0,99; dan 2,36 ppm. ${ }^{20}$ Selain itu, Kumar et al., serta Maruthupandian dan Mohan juga melaporkan hal yang sama. ${ }^{21,22}$ Dengan demikian, senyawa ester turunan asam karboksilat yang diidentifikasi dari isolat antikanker spons $H$. erecta memiliki struktur mirip dengan asam oktadeka8,10,12-trinoat sehingga juga diduga memiliki aktivitas sebagai antikanker.

\section{KESIMPULAN}

Berdasarkan hasil penelitian di atas maka dapat disimpulkan:

Isolat toksik yang diperoleh dari ekstrak etanol spons $H$. erecta yang berasal dari perairan Pulau Pari, Kepulauan Seribu, Jakarta, mempunyai aktivitas antikanker terhadap sel HeLa dengan IC $_{50}$ sebesar 30,497 ppm. Bila dibandindingkan dengan aktivitas antikanker ekstrak etanol sebelum diisolasi dengan $\mathrm{IC}_{50}$ sebesar 26,35 ppm maka terlihat adanya penurunan aktivitas yang mengindikasikan senyawasenyawa yang bersifat antikanker dalam spons $H$. erecta bersifat sinergis.

Identifikasi senyawa yang terkadung di dalam isolat antikanker ini dengan menggunakan GC-MS, teridentifikasi adanya 20 senyawa. Namun, hanya empat senyawa (senyawa pada puncak 4; 10; 15; dan 19) yang bisa dianalisis. Sedangkan 16 senyawa lagi belum bisa dianalisis karena tidak sesuai dengan database yang terdapat dalam library MS tersebut. Keempat senyawa tersebut adalah 4-nonylphenol; dibutil phtalat; ester heksadioat bis (2-etilheksil); dan kolesterol. 


\section{SARAN}

Berhubung masih ada enam belas senyawa yang terkandung dalam fraksi yang bersifat antikanker yang belum dapat diidenfikasi maka disarankan untuk mengisolasi senyawa tunggalnya dan mengidentifikasi menggunakan NMR.

\section{UCAPAN TERIMA KASIH}

Pada kesempatan ini, penulis mengucapkan terima kasih kepada semua pihak yang membantu penelitian ini. Terima kasih pula kami ucapkan kepada Direktorat Riset dan Pengabdian Masyarakat, Direktorat Jenderal Penguatan Riset dan Pengembangan, Kementerian Riset, Teknologi dan Pendidikan Tinggi, Republik Indonesia yang telah mendanai penelitian ini melalui Hibah Bersaing Tahun Anggaran 2016. Terima kasih pula kami sampaikan kepada Lembaga Penelitian dan Pengabdian kepada Masyarakat (LPPM) Universitas Udayana yang telah berperan dalam pengusulan proposal penelitian ini sampai bisa didanai. Semoga semua amal kebaikan Bapak dan Ibu mendapat pahala dari Ida Sang Hyang Widhi Wasa (Tuhan Yang Maha Esa).

\section{DAFTAR PUSTAKA}

1. Jemal, A. Murray, T. Ward, E. Samuels, A, Tiwari R. C., Ghafoor A., Feuer E.J., Thun M.J. Cancer statistics. CA Cancer J Clin 2005;55:10-30.

2. Yohana, Arisandi, dan Andriani Y. Khasiat Tanaman Obat. Jakarta: Pustaka Buku Murah; 2005.

3. Cram, W.R., Stewart, C.F., In: Herfindal, E.T., Gourley, A.B., and Hart, L.L., (Eds). Clinical Pharmacy and Therapeutics, 5th ed., Maryland USA: Williams and Wilkins. 1992.

4. Calabresi, P., and Chabner, B. In: Gilman, G.E., Rall, T.W., Taylor, O., (Eds). The Pharmacological Basics of Therapeutis, 8th, ed. Pergamon Press, USA.1991.

5. Hoppe, W. F. and Reichert, M. J. M. Predictable Annual Mass Release of Gametes By The Coral Reef Sponge Neofibularia Nolitangere (Porifera: Demospongiae). Marine biology. 1987;94:277285.

6. Lorgan, P.C., Crasey, T., and Coleman, R.E. Drugs. 1996;51:571584.

7. Green D., Tew, K.D., Hisamatsu, T., and Schein, P.S. Correlation of Nitrosourea Murine Bone Marrow Toxicity with Deoxyribonucleic Acid Alkylation and Chromatin Binding Sites. Biochem. Pharmacol. 1982;31:1671-1679.
8. Herzig R.H., Hines, J.D., and Herzin, G.P. Cerebellar toxicity with high-dose cytosine arabinoside. J. Clin. Oncol. 1987;1:927932.

9. Astuti, P., Alam, G., Hartati, M.S., Sari, D., dan Wahyuono, S. Uji Sitotoksik Senyawa Alkaloid dari Spons Petrosia sp: Potensial Pengembangan sebagai Antikanker. Majalah Farmasi Indonesia. 2005; 16(1): 58-62.

10. Pettit, G. R. Natural Product. Natural Product Report. 1996;59: 812-821.

11. Sukardiman, Rahman A, Pratiwi, F.N. Uji Praskrining Aktivitas Antikanker Ekstrak Eter dan Ekstrak Metanol Marchantia cf. planiloba Steph. Dengan Metode Uji Kematian Larva Udang dan Profil Densitometri Ekstrak Aktif. Surabaya: Fakultas Farmasi, Universitas Airlangga. 2004.

12. Widyastuti, S. Uji Toksisitas Ekstrak Daun Iprih (Ficus Glabella Blume) Terhadap Artemia salina Leach Dan Profil Kromatografi Lapis Tipis (Skripsi). Surakarta: Fakultas Farmasi, Universitas Muhammadiyah. 2008.

13. Meyer, B.N., Ferrigni, N.R., Putman, J.E., Jacobsen, L.B., Nichols, D.E., dan McLaughin, J.L., Brine Shrimp: A Convenient General Bioassay for Active Lant Constituents. Planta Medica. 1982;45:3134.

14. Steven, Colegate, Russel. Detection, Isolation, and Structural Determination of Albany California. London. Crc Press. 1993.

15. Dira Swantara, I M. dan Rita, W. S. Aktivitas antikanker ekstrak spons Hyrtios erecta. Indonesian Journal of Cancer. 2015; 9(4):141-145.

16. Sadek, P. The HPLC Solvents Guide. Wiley-Interscience. 2002.

17. Doyle, A, Griffiths, J.B. Cell and Tissue Culture For Medical Research. New York: John Wiley and Sons Ltd. 2000.

18. Cho, S. G., Valerie, H.L., Wu, X.H. Novel Cytotoxic Polyprenylated Xanthones from Garcinia gaudichaudii. Tetrahedron 1998;54:1091524.

19. Ohashi, K., Winarno, H., Mukao, M., Shibuya, H. Preparation and Cancer Cell Invasion Inhibitory Effects of C-16 Alkynic Fatty Acid. Chem. Pharm. Bull. 2003;51(4):463-466

20. Winarno, H. Antiproliferative Activity of Octadeca-8,10,12-trynoic Acid Agains Human Cancer Cell Lines. Berita-Biologi. 2009; 9(4):343-348.

21. Kumar, P. Praveen, S. Kumaravel and Lalitha, C. Screening of Antioxidant Activity, Total Phenolics and GC-MS Study of Vitex Negundo. African Journal of Biochemistry Research. 2010;4(7): 191-195.

22. Maruthupandian, A. and Mohan, V.R. GC-MS analysis of some bioactive constituents of Pterocarpus marsupium R. International Journal of ChemTech Research. 2011;3(3): 1652-1657. 